\title{
Grounding osteopathic research Introducing grounded theory
}

\author{
Oliver P. Thomson, Nicola J. Petty, Julie Scholes
}

\begin{abstract}
Over the last four decades there has been a proliferation of qualitative research into healthcare practice, including manual therapy. Grounded theory is the most widely used qualitative research methodology, and has contributed to the knowledge base of a number of healthcare professions. This Masterclass provides an introduction to grounded theory and uses a recent doctoral study into osteopathic clinical decision-making as an example to illustrate the main processes and procedures when conducting and evaluating grounded theory research. This paper highlights how grounded theory research may be of help in developing a robust and rounded evidence-base in relation to osteopathic practice.
\end{abstract}

\section{KEYWORDS}

Grounded theory; Qualitative research; Methodology; Research methods; Qualitative data anal- ysis;

Decision-making; Clinical reasoning; Osteopathy; Osteopathic medicine

\section{Introduction}

Qualitative research methodologies have been used in the social sciences for over half a decade, and in recent years the value that qualitative approaches can add to the knowledge bases of a range of manual therapy professions has been highlighted, for example in musculoskeletal physiotherapy, ${ }^{105}$ chiropractic $^{6}$ and osteopathy. ${ }^{7}$ Since 
the inception of the International Journal of Osteopathic Medicine in 2001, 68 original articles have been published, of which 5 (7\%) have taken a qualitative approach (Table 1). The dominance that quantitative research has had in healthcare means that many practitioners will be unfamiliar with the variety of different qualitative methodologies and how these can help inform clinical practice. This Masterclass aims to provide the reader with an introduction to one of the most popular qualitative research approaches, grounded theory. A comprehensive and systematic literature search has identified that between 1991 and 1998, out of a total of 4134 citations in the Social Science Citation Index ( $\mathrm{SCCl})$, to all types of methods (both quantitative and qualitative), 'grounded theory' received 2662 citations (64\%). ${ }^{8}$ Whilst this illustrates its popularity, the high number of citations for 'grounded theory' in the $\mathrm{SCCl}$ makes no guarantee of the quality nor the type of grounded theory that is being cited. ${ }^{8}$

To illustrate the main procedures of grounded theory, examples will be provided from a recent doctoral study which used the approach to explore the clinical decision-making and therapeutic approaches of experienced osteopaths in the UK. ${ }^{9 \mathrm{e} 11}$

\section{Qualitative research e a paradigm shift}

The important role that qualitative research has in building a robust evidence base in osteopathy lies in its ability to embrace both the patient-centred and biopsychosocial models of healthcare. ${ }^{7,19}$ In line with these models of healthcare, qualitative research recognises the individuality of patients' perspectives and experiences and seeks to explore and understand them. In contrast, quantitative research, often using randomised controlled trials tends to view individual patient characteristics as unwanted variables which need to be controlled, and attempts to obtain as homogeneous sample as possible. ${ }^{20}$ The findings from quantitative research are able to generate valuable knowledge to help inform the 'technical-rational' aspects of practice, ${ }^{21}$ such as the reliability and validity of clinical testing procedures or the risks (and benefits) associated with treatment interventions. Whereas qualitative research has the capacity to explore the many different types of knowledge associated with practice, which are often concealed from quantitative research, such as: embodied knowledge ${ }^{22}$; tacit knowledge ${ }^{23}$; professional craft knowledge ${ }^{24,25}$; and scientific knowledge. ${ }^{26}$ In this respect, qualitative research recognises the 'professional-artistic'21,27,28 side of practice (such as how practitioners make clinical judgements during complex and uncertain situations), which is often improvised, tacit ${ }^{23}$ and difficult to access using quantitative research. Table 2 summarises and compares three commonly used qualitative research approaches; phenomenology, discourse analysis and the focus of this paper, grounded theory.

The differences in quantitative and qualitative research approaches are due to very different theoretical and philosophical assumptions about knowledge and reality, which together form a research paradigm. Typically, a positivist/postpositivist paradigm underpins quantitative research and an interpretive/constructionist paradigm underpins qualitative research approaches. ${ }^{30}$ The philosophical orientations of positivism/postpositivism assume a stable, single and objective reality that can be observed, so that evidence can be gathered and measured in a systematic way to generate knowledge. ${ }^{4}$ In contrast, interpretivism/ constructionism maintains that there are multiple subjective realities and that knowledge and meaning is not automatically 'out there' or present in objects or social situations, it is created and constructed by individuals. ${ }^{1}$ The major differences between these two research paradigms are summarised in Table 3. We argue that both quantitative and qualitative research approaches are necessary for osteopathy to develop a robust evidence base which can help explain and understand the complexities of clinical practice and enhance patient care.

\section{Grounded theory e an introduction}

Grounded theory involves systematic methods of gathering, analysing and conceptualising data so that a theory can be built to explain a social process, action or interaction. ${ }^{32}$ Originally described in the 1960 s by two social scientists, Barney G. Glaser and Anselm L. Strauss, their book The Discovery of Grounded Theory ${ }^{33}$ was revolutionary in that it challenged the then dominant quantitative research methods used in sociological research. ${ }^{34}$ Prior to the conception of grounded theory, most social research involved utilising existing sociological constructs and theories to analysis research data (such as a predetermined coding framework developed by existing literature, theory and research). Therefore, the findings were seen as only verifying the existing 'grand theories' rather than producing new theories to explain social processes. Glaser and Strauss proposed that grounded theory would allow for the 'discovery' of new theory rather than merely describing social 
Table 1 Summary of original qualitative research articles published in The International Journal of Osteopathic Medicine since 2001.

\begin{tabular}{|c|c|c|c|c|c|c|c|}
\hline No. & Author & Research area & Methodology & Participants & Data collection & Data analysis & Findings \\
\hline 1 & $\begin{array}{l}\text { Grundy \& } \\
\text { Vogel }^{12} \text { (UK) }\end{array}$ & $\begin{array}{l}\text { Attitudes of UK } \\
\text { osteopaths } \\
\text { towards } \\
\text { prescribing } \\
\text { rights. }\end{array}$ & Grounded theory. ${ }^{13}$ & $\begin{array}{l}10 \text { practicing } \\
\text { osteopaths. }\end{array}$ & $\begin{array}{l}\text { Focus group } \\
\text { interviews. }\end{array}$ & $\begin{array}{l}\text { Constant } \\
\text { comparative } \\
\text { method; codes; } \\
\text { themes. }\end{array}$ & $\begin{array}{l}\text { Three ideological themes } \\
\text { representing extreme } \\
\text { positions of osteopaths' views } \\
\text { on prescribing rights, labelled } \\
\text { as 'Scientific osteopathy', } \\
\text { 'Osteopathic purity' and } \\
\text { 'Osteopathic prescribing'. }\end{array}$ \\
\hline 2 & $\begin{array}{l}\text { Zamani } \\
\text { et al., }{ }^{14} \text { (UK) }\end{array}$ & $\begin{array}{l}\text { Analysis of } \\
\text { exercise content } \\
\text { in undergraduate } \\
\text { osteopathic } \\
\text { education. }\end{array}$ & Unspecified. & $\begin{array}{l}7 \text { osteopathic } \\
\text { educational } \\
\text { institutions. }\end{array}$ & $\begin{array}{l}\text { Course curricula } \\
\text { (documents). }\end{array}$ & $\begin{array}{l}\text { Content analysis e } \\
\text { codes; categories; } \\
\text { inter-coder } \\
\text { agreement between } \\
\text { two researchers. }\end{array}$ & $\begin{array}{l}\text { Exercise content was variable } \\
\text { in quantity and quality; } \\
\text { exercise as part of wider } \\
\text { public health promotion and } \\
\text { education was not explicitly } \\
\text { addressed. }\end{array}$ \\
\hline 3 & $\begin{array}{l}\text { Carnes \& } \\
\text { Underwood } \\
\text { (UK) }\end{array}$ & $\begin{array}{l}\text { Monitoring } \\
\text { patient's ability } \\
\text { to achieve } \\
\text { functional tasks } \\
\text { in those with } \\
\text { musculoskeletal } \\
\text { pain. }\end{array}$ & $\begin{array}{l}\text { Phenomenological/ } \\
\text { ethnometh- } \\
\text { odological. }\end{array}$ & $\begin{array}{l}13 \text { patients with } \\
\text { chronic low back pain. }\end{array}$ & In-depth interviews. & Codes; themes. & $\begin{array}{l}\text { Treatment progress } \\
\text { can be more meaningfully } \\
\text { monitored by using patient } \\
\text { determined goals, rather } \\
\text { than practitioner determined } \\
\text { clinical outcomes. }\end{array}$ \\
\hline 4 & $\begin{array}{l}\text { Hartup } \\
\text { et al., } \\
\text { (Australia) }\end{array}$ & $\begin{array}{l}\text { Exploration of } \\
\text { the lived } \\
\text { experience of } \\
\text { being an } \\
\text { osteopathic } \\
\text { student. }\end{array}$ & $\begin{array}{l}\text { Phenomenological } \\
\text { approach. }{ }^{17}\end{array}$ & $\begin{array}{l}19 \text { osteopathic } \\
\text { students. }\end{array}$ & In-depth interviews. & $\begin{array}{l}\text { Codes; themes; } \\
\text { clustering. }\end{array}$ & $\begin{array}{l}\text { Five main stages of the } \\
\text { emotional experiences of } \\
\text { students' progression through } \\
\text { osteopathic training. }\end{array}$ \\
\hline 5 & $\begin{array}{l}\text { Humpage }^{18} \\
\text { (UK) }\end{array}$ & $\begin{array}{l}\text { Opinions on } \\
\text { research and } \\
\text { evidence based } \\
\text { medicine within } \\
\text { the UK } \\
\text { osteopathic } \\
\text { profession. }\end{array}$ & Unspecified. & $\begin{array}{l}\text { Public documents } \\
\text { between } 2003 \text { and } \\
2009 .\end{array}$ & $\begin{array}{l}\text { Osteopathic } \\
\text { magazines, } \\
\text { websites, forum } \\
\text { posts. }\end{array}$ & $\begin{array}{l}\text { Thematic analysis } \\
\text { (themes). }\end{array}$ & $\begin{array}{l}\text { A conceptual model of issues } \\
\text { relating to research and } \\
\text { evidence based-medicine in } \\
\text { osteopathy. }\end{array}$ \\
\hline
\end{tabular}


Table 2 Summary of three commonly used qualitative research approaches (modified from Starks and BrownTrinidad $\left.^{29}\right)$.

\begin{tabular}{|c|c|c|c|}
\hline & Grounded theory & Phenomenology & Discourse analysis \\
\hline Historical roots & Sociology & European philosophy & Linguistics/Semiotics \\
\hline $\begin{array}{l}\text { Theoretical } \\
\text { underpinning }\end{array}$ & $\begin{array}{l}\text { Pragmatism, symbolic } \\
\text { interactionism. }\end{array}$ & $\begin{array}{l}\text { Existentialism, } \\
\text { hermeneutic philosophy, } \\
\text { psychology. }\end{array}$ & $\begin{array}{l}\text { Critical social theory, post-structural } \\
\text { and post-modernist feminism. }\end{array}$ \\
\hline Philosophy & $\begin{array}{l}\text { Theory is discovered/ } \\
\text { constructed by } \\
\text { examining concepts } \\
\text { grounded in the data. }\end{array}$ & $\begin{array}{l}\text { There exists an essential, } \\
\text { perceived reality with } \\
\text { common features }\end{array}$ & $\begin{array}{l}\text { Knowledge and meaning is produced } \\
\text { through interactions with multiple } \\
\text { discourses. }\end{array}$ \\
\hline Goal & $\begin{array}{l}\text { Generate an } \\
\text { explanatory theory of } \\
\text { social process, action } \\
\text { and interaction. }\end{array}$ & $\begin{array}{l}\text { Describe the meaning of } \\
\text { the lived experience of a } \\
\text { phenomenon. }\end{array}$ & $\begin{array}{l}\text { Understand how people use language } \\
\text { to create and enact identities and } \\
\text { activities }\end{array}$ \\
\hline Product & $\begin{array}{l}\text { A theory generated } \\
\text { from the range of } \\
\text { participants } \\
\text { perspectives and } \\
\text { experiences. }\end{array}$ & $\begin{array}{l}\text { A thematic description of } \\
\text { the pre-given 'essences' } \\
\text { and structures of lived } \\
\text { experiences. }\end{array}$ & $\begin{array}{l}\text { Description of language-in-use; } \\
\text { identify how different discourses } \\
\text { shape how identities, relationships } \\
\text { and social goods are negotiated and } \\
\text { produced. }\end{array}$ \\
\hline $\begin{array}{l}\text { Example research } \\
\text { question }\end{array}$ & $\begin{array}{l}\text { "How do osteopaths act } \\
\text { and interact with } \\
\text { patients in the context } \\
\text { of their clinical work, } \\
\text { and what are the social } \\
\text { processes involved?" }\end{array}$ & $\begin{array}{l}\text { "What is the lived } \\
\text { experience of people with } \\
\text { chronic low back pain?" }\end{array}$ & $\begin{array}{l}\text { "What discourses are used and how } \\
\text { do they shape tutor-student } \\
\text { identities, activities and } \\
\text { relationships in osteopathic clinical } \\
\text { education?" }\end{array}$ \\
\hline
\end{tabular}

processes and verifying existing theories. ${ }^{33}$ Therefore, grounded theory may be useful for researchers wishing to generate new explanatory theory to help understand issues of importance in clinical practice, specifically focusing on social processes, actions and interactions.

\section{What is a grounded theory?}

The term 'theory' is used to denote an explanation that "systematically integrates various concepts through statements of relationships" 35 , p. 25 and thus explains a phenomenon or process. The term 'grounded' is used as the theory which is generated is inextricably linked with the data and therefore is 'grounded' in the data. ${ }^{36}$ The original grounded theory, as conceived by Glaser and Strauss $^{33}$ was developed at a time when social research was seen as 'soft' compared to the 'harder' disciplines of the natural sciences, where quantitative research was dominant. In striving for academic respectability Glaser and Strauss wanted grounded theory to be seen as rigorous and

Table 3 Comparison of the core assumptions underpinning positivist/post-positivist and interpretive/constructionist research paradigms. ${ }^{30,31}$

\begin{tabular}{lll}
\hline & $\begin{array}{l}\text { Positivist/post-positivist } \\
\text { paradigm }\end{array}$ & $\begin{array}{l}\text { Interpretive/constructionist } \\
\text { paradigm }\end{array}$ \\
\hline $\begin{array}{l}\text { Ontology (the nature of being } \\
\text { and reality) }\end{array}$ & $\begin{array}{l}\text { Realism, critical realism. } \\
\text { Single, objective 'real' } \\
\text { reality. }\end{array}$ & $\begin{array}{l}\text { Relativism. Multiple realities } \\
\text { which are socially } \\
\text { constructed. }\end{array}$ \\
$\begin{array}{ll}\text { Epistemology (how it is } \\
\text { possible to gain knowledge }\end{array}$ & $\begin{array}{l}\text { Objectivism, dualist. Able to } \\
\text { directly observe reality. }\end{array}$ & $\begin{array}{l}\text { Subjectivism/constructivism. } \\
\text { of this reality) }\end{array}$ \\
$\begin{array}{ll}\text { Data } \\
\text { Position of the researcher }\end{array}$ & Use numbers to measure. & Subjectivity of observer. \\
& Researcher is distant, & Findings are co-constructed. \\
Aim of research & objective and detached. & Uses words and language. \\
& To explain, predict and & Researcher is close, \\
control. & subjective and participatory. \\
& & To generate a contextual \\
\end{tabular}


'scientific' and in doing so the original conception of grounded theory is generally considered as having positivist/post-positivist philosophical roots (Table 3), even if the authors are not explicit is stating so. ${ }^{36}$

The contrasting backgrounds of the originators are often claimed to have laid the philosophical roots of grounded theory. ${ }^{37 e 39}$ Strauss was influenced by American Pragmatism and Symbolic Interactionism that emphasised qualitative research. Symbolic interactionism refers to the premise that the process of human interaction provides the meanings for the experiences that individuals may have. ${ }^{40}$ The perspective that symbolic interactionism holds is that human behaviour and action is based upon the meaning that individuals place on symbols (people and things), and how such meaning is interpreted and communicated through language. Central to the theory of symbolic interactionism is that meaning is constructed through the interaction between people, rather than meaning being assumed or 'intrinsically emanating' from the symbol. ${ }^{40}$ Whereas, the theoretical position of pragmatism considers that by acting and interacting (often during a problematic situation), people can creatively develop knowledge of the world, which may be usable in practice. ${ }^{41}$ Charmaz adds that pragmatism considers reality as "fluid" and open to multiple interpretations, and therefore pragmatists see truth as "relativistic and provisional." 39, p. 187

In contrast to Strauss, Glaser's extensive quantitative research training emphasised systematic empirical sociological research, and whilst not intentional, some authors suggest his background accounts for the positivist/post-positivist notions threaded through early grounded theory literature. ${ }^{36,42}$ The philosophical perspectives of symbolic interactionism and positivism signify a coming together of two competing traditions in sociological research, ${ }^{39}$ and this has been suggested as being largely responsible for the originators' acrimonious separation in the 1980s. It is thought that the differences that emerged between Glaser and Strauss are symptomatic of the troubled alignment of assumptions that lie at the heart of grounded theory. ${ }^{36}$

Over the last four decades there has been a growing interest in healthcare research conducted in the interpretive paradigm, and combined with the positivist leanings of the original grounded theory methodology (and as a consequence of the split between Glaser and Strauss), there are now several different 'versions' of grounded theory, with different theoretical approaches (see Morse ${ }^{43}$ for a full discussion). With the increasing use of grounded theory by researchers ${ }^{8}$ and a number of different permutations of the approach, many researchers claim to use a grounded theory methodology, but frequently on closer inspection it is just a few features being employed (such as coding). With this in mind, the defining attributes of grounded theory are outlined in Table 4.

Since its conception in the 1960s, three major approaches to grounded theory have evolved, each with different theoretical positions. These are: Glaser's 'Glaserian' or 'Classic' grounded theory, ${ }^{44,45}$ Strauss and Corbin's pragmatic-symbolic interactionist approach to grounded theory ${ }^{41,46,47}$; and finally, Charmaz's constructivist grounded theory. ${ }^{34,39}$ While all three grounded theorists (Glaser, Strauss and Charmaz) may 'agree' that the characteristics illustrated in Table 4 are fundamental ingredients of grounded theory research, their different philosophical positions have resulted in variation in how the features are conceived and applied during a research study. For example, there is wide variation in the descriptions of the coding processes used during data analysis, and how the researcher 'discovers' or 'constructs' codes from data. Birks and Mills ${ }^{32}$ highlight that coding in grounded theory ranges from vague and ambiguous (e.g. the early grounded theory literature by Glaser and Strauss ${ }^{33}$ ) to elaborate and complicated (e.g. Strauss and Corbin's coding paradigm $^{48}$ or Glaser's theoretical coding families ${ }^{44}$ ) 'and finally to coding which is open, flexible and more straightforward (e.g. Charmaz's initial coding and focused coding ${ }^{39}$ ).

To provide some clarity amongst the different approaches to grounded theory, Charmaz ${ }^{34}$ makes the distinction between 'objectivist' and 'constructivist' grounded theory depending on the philosophical position of the researcher and the research paradigm in which the study is located.

Table 4 Key defining characteristics of grounded theory. ${ }^{39}$

Characteristic

1. Simultaneous data collection and analysis.

2. Construction of codes and categories.

3. Using the constant comparative method of analysis.

4. Advancing theory development during each step of data collection and analysis.

5. Memo-writing.

6. Purposeful and theoretical sampling.

7. Conducting a comprehensive literature review after data analysis. 
An awareness of these theoretical positions will enable researchers to make an informed decision of the version of grounded theory to employ, and which will either lead to the 'discovery' or 'construction' of their theory. These differences in grounded theory are summarised in Table 5.

A researcher leaning towards a positivist theoretical view may consider that theory is 'out there' to be observed and discovered and represents the truth of the social phenomena or process being studied. The researcher would thus employ an objectivist approach to grounded theory, also termed 'Classic' or 'Glaserian' grounded theory. ${ }^{33,44,45}$ Alternatively, a researcher leaning towards an interpretive view may consider that theory is constructed though an active process of interpretation of data and that the findings represent one of a number of possible theories (or truths) to understand the area under study. In this case, a constructivist form of grounded theory ${ }^{39,49,50}$ may be more congruent with the views of the researcher. However, many authors now agree that grounded theory may be used with a range of underpinning epistemologies ranging from positivism to interpretivism. ${ }^{42,51,52}$ Central to all grounded theory research is the rigour and robustness in the analytical processes of the approach, such as those detailed in Table 4 . With that said, Glaser has adhered rigidly to his original Classic version of grounded theory and considers that researchers deviating from his original approach (including those adopting constructivist approaches) are employing generic 'qualitative data analysis' (QDA) ${ }^{53,54}$ rather than (in his view) 'true' grounded theory. Glaser maintains that QDA produces a superficial descriptive account rather than a conceptual grounded theory. ${ }^{54}$ Our view is in line with others ${ }^{34,36,39,42,55}$ that theoretical inclusivity reflects a healthy generational evolution and modern progression of original grounded theory.

\section{The value of grounded theory in manual therapy research}

Grounded theory has been used by a range of healthcare professions including physiotherapy, ${ }^{56 e 59}$ nursing ${ }^{60 e 63}$ and medicine. ${ }^{64,65}$ Some examples of grounded theory research by the manual therapy professions are provided in Table 6. Many of these researchers have used grounded theory to understand the complex, multidimensional and discrete areas of practice. To illustrate this, one study is explored here in further detail. Physiotherapy researchers in the USA conducted a grounded theory study on the nature of clinical expertise of physiotherapists. ${ }^{58,66}$ These researchers set out to address the research questions: "are there differences between how expert physical therapy clinicians and novice physical therapy clinicians practice? and, if so, what are the differences and how do the differences develop?". ${ }^{66,}$ p. 746 This now seminal grounded theory research explicated what was a previously unknown area of practice and highlighted the attributes of expert clinical practice. This contribution to physiotherapy knowledge had important implications for both practitioners and educators within the physiotherapy profession and has led to further research into clinical reasoning ${ }^{57,67 e 70}$ and expertise. ${ }^{59,71 e 73}$

\section{Case example of a grounded theory research study}

As part of a PhD, the first author (OT) embarked on a grounded theory study to explore the clinical decision-making and therapeutic approaches of experienced osteopaths in the UK. ${ }^{9} 11$ Grounded theory was considered to be an appropriate methodology as it would result in the construction of an explanatory theory which would help understand the processes of osteopathic clinical

Table 5 Major differences between constructivist and objectivist grounded theory.

\begin{tabular}{|c|c|c|}
\hline Version of grounded theory & $\begin{array}{l}\text { Constructivist grounded } \\
\text { theory } 32,34,38,39,42,49,52,55\end{array}$ & Objectivist grounded theory ${ }^{33,44,45}$ \\
\hline Research paradigm & Interpretive/constructionist. & Positivist/post-positivist. \\
\hline Role of the researcher & $\begin{array}{l}\text { Interactive, participatory and } \\
\text { reflexive. }\end{array}$ & Passive, objective and detached. \\
\hline Analysis & $\begin{array}{l}\text { Codes and categories are actively } \\
\text { constructed through an active } \\
\text { interpretive process. }\end{array}$ & $\begin{array}{l}\text { Codes, categories and patterns } \\
\text { passively emerge from the data. }\end{array}$ \\
\hline Theory & $\begin{array}{l}\text { Theory is constructed and } \\
\text { represents a re-construction of } \\
\text { multiple realities. }\end{array}$ & $\begin{array}{l}\text { Theory is there to be discovered } \\
\text { and represents the facts of a real } \\
\text { and external reality. }\end{array}$ \\
\hline
\end{tabular}


Table 6 Examples of grounded theory research in the physical and manual therapy professions.

\begin{tabular}{|c|c|c|c|c|c|c|c|}
\hline No. & Authors & Profession & Research area & $\begin{array}{l}\text { Version of } \\
\text { grounded theory }\end{array}$ & Participants & Data collection & Findings \\
\hline 1 & Jamison $^{74}$ & $\begin{array}{l}\text { Chiropractic } \\
\text { (Australia) }\end{array}$ & $\begin{array}{l}\text { Patient-practitioner } \\
\text { interaction and } \\
\text { communication. }\end{array}$ & Charmaz $^{39}$ & 34 chiropractors. & $\begin{array}{l}\text { Clinical } \\
\text { observations. }\end{array}$ & $\begin{array}{l}\text { Interaction observed in } \\
\text { chiropractic practice is } \\
\text { bidirectional, is both } \\
\text { task- and relationship- } \\
\text { oriented. Touch, } \\
\text { whether diagnostic or } \\
\text { therapeutic, emerged } \\
\text { as a fundamental } \\
\text { feature of chiropractic } \\
\text { care. }\end{array}$ \\
\hline 2 & $\begin{array}{l}\text { Jensen } \\
\text { et al., }{ }^{58}\end{array}$ & $\begin{array}{l}\text { Physiotherapy } \\
\text { (USA) }\end{array}$ & $\begin{array}{l}\text { Expert practice in } \\
\text { physical therapy. }\end{array}$ & $\begin{array}{l}\text { Strauss and } \\
\text { Corbin }^{35}\end{array}$ & $\begin{array}{l}12 \text { peer-designated } \\
\text { expert physical } \\
\text { therapists. }\end{array}$ & $\begin{array}{l}\text { Interviews, } \\
\text { nonparticipant } \\
\text { observations, } \\
\text { videorecording patient } \\
\text { treatment sessions, } \\
\text { and review of } \\
\text { documents (e.g., } \\
\text { published papers, } \\
\text { teaching materials, } \\
\text { patient records). }\end{array}$ & $\begin{array}{l}\text { A theoretical model of } \\
\text { expert practice in } \\
\text { physical therapy. }\end{array}$ \\
\hline 3 & $\begin{array}{l}\text { Jette } \\
\text { et al., }{ }^{56}\end{array}$ & $\begin{array}{l}\text { Physiotherapy \& } \\
\text { occupational } \\
\text { therapy (USA) }\end{array}$ & $\begin{array}{l}\text { Decision-making } \\
\text { process of physical } \\
\text { and occupational } \\
\text { therapists when } \\
\text { recommending } \\
\text { discharge destination } \\
\text { for patients following } \\
\text { acute care } \\
\text { hospitalisation. }\end{array}$ & Glaser $^{45}$ & $\begin{array}{l}7 \text { physiothera- } \\
\text { pists and } 2 \\
\text { occupational } \\
\text { therapists in an } \\
\text { acute care setting. }\end{array}$ & $\begin{array}{l}\text { Semi-structured } \\
\text { interviews. }\end{array}$ & $\begin{array}{l}\text { A grounded theory } \\
\text { model for discharge } \\
\text { decision-making. The } \\
\text { basic social process } \\
\text { involved the therapists' } \\
\text { use of clinical reasoning } \\
\text { to arrive at what they } \\
\text { believed were the best } \\
\text { possible. } \\
\text { recommendations for } \\
\text { discharge destinations. }\end{array}$ \\
\hline \multirow[t]{2}{*}{4} & $\begin{array}{l}\text { Edwards } \\
\text { et al., }, 7\end{array}$ & $\begin{array}{l}\text { Physiotherapy } \\
\text { (Australia) }\end{array}$ & Clinical reasoning. & $\begin{array}{l}\text { Strauss and } \\
\text { Corbin }^{75}\end{array}$ & $\begin{array}{l}12 \text { expert physical } \\
\text { therapists ( } 6 \text { were } \\
\text { peer nominated). }\end{array}$ & $\begin{array}{l}\text { Interview data, } \\
\text { observation, } \\
\text { reflective diaries. }\end{array}$ & $\begin{array}{l}\text { Clinical reasoning in } \\
\text { physical therapy was } \\
\text { characterised by } \\
\text { different clinical } \\
\text { reasoning 'strategies' } \\
\text { and the application of } \\
\text { different paradigms of } \\
\text { knowledge. }\end{array}$ \\
\hline & & & & & & & (continued on next page) \\
\hline
\end{tabular}




\begin{tabular}{|c|c|c|c|c|c|c|c|}
\hline No. & Authors & Profession & Research area & $\begin{array}{l}\text { Version of } \\
\text { grounded theory }\end{array}$ & Participants & Data collection & Findings \\
\hline 5 & $\begin{array}{l}\text { Evans } \\
\text { et al., } \\
\text { (for full } \\
\text { discussion } \\
\text { see Evans) }\end{array}$ & $\begin{array}{l}\text { Physical therapies } \\
\text { (osteopathy, } \\
\text { chiropractic and } \\
\text { physiotherapy) } \\
\text { (UK) }\end{array}$ & $\begin{array}{l}\text { Treatment and } \\
\text { management } \\
\text { approaches of } \\
\text { patients with } \\
\text { low back pain. }\end{array}$ & $\begin{array}{l}\text { Strauss and } \\
\text { Corbin }^{35}\end{array}$ & $\begin{array}{l}8 \text { osteopaths } \\
9 \text { chiropractors } \\
13 \text { musculoske- } \\
\text { letal physiothe- } \\
\text { rapists. }\end{array}$ & $\begin{array}{l}\text { Focus group } \\
\text { interviews. }\end{array}$ & $\begin{array}{l}\text { A theoretical model of } \\
\text { the factors which } \\
\text { influence the behaviour } \\
\text { of individual } \\
\text { chiropractors, } \\
\text { osteopaths and } \\
\text { musculoskeletal } \\
\text { physiotherapists when } \\
\text { caring for patients } \\
\text { with low back pain. }\end{array}$ \\
\hline 6 & $\begin{array}{l}\text { Chaffey } \\
\text { et al., } 78\end{array}$ & $\begin{array}{l}\text { Occupational } \\
\text { therapy } \\
\text { (Australia) }\end{array}$ & $\begin{array}{l}\text { Intuition among } \\
\text { occupational } \\
\text { therapists. }\end{array}$ & $\begin{array}{l}\text { Charmaz }^{39} \\
\text { Strauss }^{13}\end{array}$ & $\begin{array}{l}9 \text { occupational } \\
\text { therapists } \\
\text { working in mental } \\
\text { health practice. }\end{array}$ & $\begin{array}{l}\text { Semi-structured } \\
\text { interviews. }\end{array}$ & $\begin{array}{l}\text { A theoretical model } \\
\text { which suggested that } \\
\text { intuition was an } \\
\text { instinctive } \\
\text { understanding of } \\
\text { situations, resulting } \\
\text { from professional } \\
\text { experience and the } \\
\text { understanding of } \\
\text { emotions. }\end{array}$ \\
\hline 7 & $\begin{array}{l}\text { Petty } \\
\text { et al . } 72,73,79\end{array}$ & $\begin{array}{l}\text { Physiotherapy } \\
\text { (UK) }\end{array}$ & $\begin{array}{l}\text { Students' } \\
\text { experience of } \\
\text { completing a } \\
\text { musculoskeletal } \\
\text { Masters (MSc) } \\
\text { course. }\end{array}$ & $\begin{array}{l}\text { Schatzm- } \\
\text { an }^{80}\end{array}$ & $\begin{array}{l}11 \text { alumni from } \\
\text { one MSc } \\
\text { programme. }\end{array}$ & $\begin{array}{l}\text { Semi-structured } \\
\text { interviews, } \\
\text { participant profiles; } \\
\text { researcher's } \\
\text { observational } \\
\text { memory. }\end{array}$ & $\begin{array}{l}\text { An explanatory theory } \\
\text { of the learning } \\
\text { transition } \\
\text { of students and their } \\
\text { development towards } \\
\text { clinical expertise. }\end{array}$ \\
\hline 8 & Sexton ${ }^{81}$ & $\begin{array}{l}\text { Physiotherapy } \\
\text { (UK) }\end{array}$ & $\begin{array}{l}\text { Patient- } \\
\text { centeredness in } \\
\text { relation to low- } \\
\text { back pain. }\end{array}$ & $\begin{array}{l}\text { Strauss and } \\
\text { Corbin }^{35}\end{array}$ & $\begin{array}{l}9 \text { musculoskeletal } \\
\text { physiotherapists. }\end{array}$ & $\begin{array}{l}\text { Semi-structured } \\
\text { interviews. }\end{array}$ & $\begin{array}{l}\text { A theoretical model } \\
\text { conceptualising } \\
\text { patient-centred care } \\
\text { in musculoskeletal } \\
\text { physiotherapy. }\end{array}$ \\
\hline
\end{tabular}


decision-making, which was considered a cognitive, interactive and social process. ${ }^{82}$

Before commencing the study OT familiarised himself with the objectivist ${ }^{33,44,45}$ and constructivist $^{38,39,50}$ approaches to grounded theory (Table 5 ), and the merits and criticisms of each, so that he could locate himself and the research on the 'methodological spiral' of grounded theory. ${ }^{42} \mathrm{~A}$ constructivist approach to grounded theory was chosen as it would acknowledge that osteopaths participating in the study would have unique experiences and therefore there would be multiple realties in relation to clinical decision-making ${ }^{34}$; this was congruent with the personal assumptions of OT. Furthermore, in taking a grounded theory approach, this research followed in the footsteps of researchers in the physiotherapy profession who used grounded theory to help understand clinical expertise and decision-making. ${ }^{57 e 59,72,73}$

The main methodological processes used in grounded theory (Fig. 1) are now discussed with reference to the case example.

\section{The role of the literature review in groun- ded theory}

The original grounded theory ${ }^{33}$ and later works by Glaser $^{44}$ advocated being 'theoretically sensitive', by not entering the field with a priori knowledge, and the researcher not committing themselves to specific preconceived theories. ${ }^{33}$ Bryant suggests that the notion that the researcher's previous ideas and knowledge can be "turned on and off like a tap" is unrealistic. ${ }^{84, \text { p. }} 3$ If it were possible, this would place the researcher in a "totally neutral position" as a "dispassionate, passive observer". ${ }^{84, ~ p . ~}{ }^{3}$ As OT possessed an awareness of some of the existing theories of clinical reasoning and decision-making prior to conducting the research as well as his own clinical osteopathic experience, attempting to discard this a priori knowledge would constitute a positivistic "evasion of cognition" 85, p. 7 and would not be congruent with the constructivist approach taken in this study.

The interpretation of not entering the field with a priori knowledge is sometimes assumed to mean

\footnotetext{
${ }^{\mathrm{e}}$ Mills et al. ${ }^{49}$ use the notion of 'methodological spiral' to refer to the different epistemological and ontological positions that grounded theory researchers have taken through the passage of time. The spiral would begin with early objectivist grounded theory as posited by Glaser and Strauss ${ }^{33}$ and Glaser, ${ }^{44}$ and spiral down towards more recent constructionist iterations of grounded theory..$^{39,83}$
}

that the literature is not explored until data analysis has been complete. However, Glaser advocates the researcher having a thorough knowledge of social processes and one can assume this includes broad readings of the literature; what is perhaps critical is that the researcher is led by the data and is not committed to specific preconceived theories that are then applied onto the data leading to 'forced theory'. ${ }^{44}$ Either way, researchers cannot avoid looking at literature early in the process to identify gaps, develop research questions and submit ethical and grant applications. However in this instance the literature is likely to be a broad reading of the general area. Furthermore the theory is produced from the data (i.e. 'grounded') and typical of qualitative data analysis this follows many unpredictable twists and turns. The researcher may later explore relevant literature to 'sharpen their nose' as they progressively focus on concepts derived from the data during analysis ${ }^{86}$; in this instance the literature is used to theoretically sensitise the researcher to see the theoretical possibilities in the data. Once the analysis is complete and a substantive theory has been generated, it is compared and contrasted with specific theoretical literature to integrate the new theory into existing theories.

For the case example of osteopathic clinical decision-making, the choice as to when and how to consult the extant literature was initially determined by the regulations and expectations of the $\mathrm{PhD}$ programme. Like most research programmes, OT was required early on in the doctorate to outline and justify the research study and its potential contribution to the knowledge base of osteopathy. This involved reading research papers that had explored clinical reasoning both within osteopathy and other healthcare professions. Later on, during data analysis the extant literature was consulted in order to enhance OT's theoretical sensitivity to concepts developed from data analysis.

\section{Sampling in grounded theory research}

Grounded theory, like many other qualitative research methodologies initially takes a purposive approach to sampling. Purposive sampling involves the intentional selection of information-rich cases from which one can learn a great deal about issues of central importance to the purpose of the research. ${ }^{87}$ This is in agreement with one of the founders of grounded theory, Glaser, who acknowledges that in the initial stages of a study the researchers should go to the groups which they believe will maximise the possibilities of obtaining 


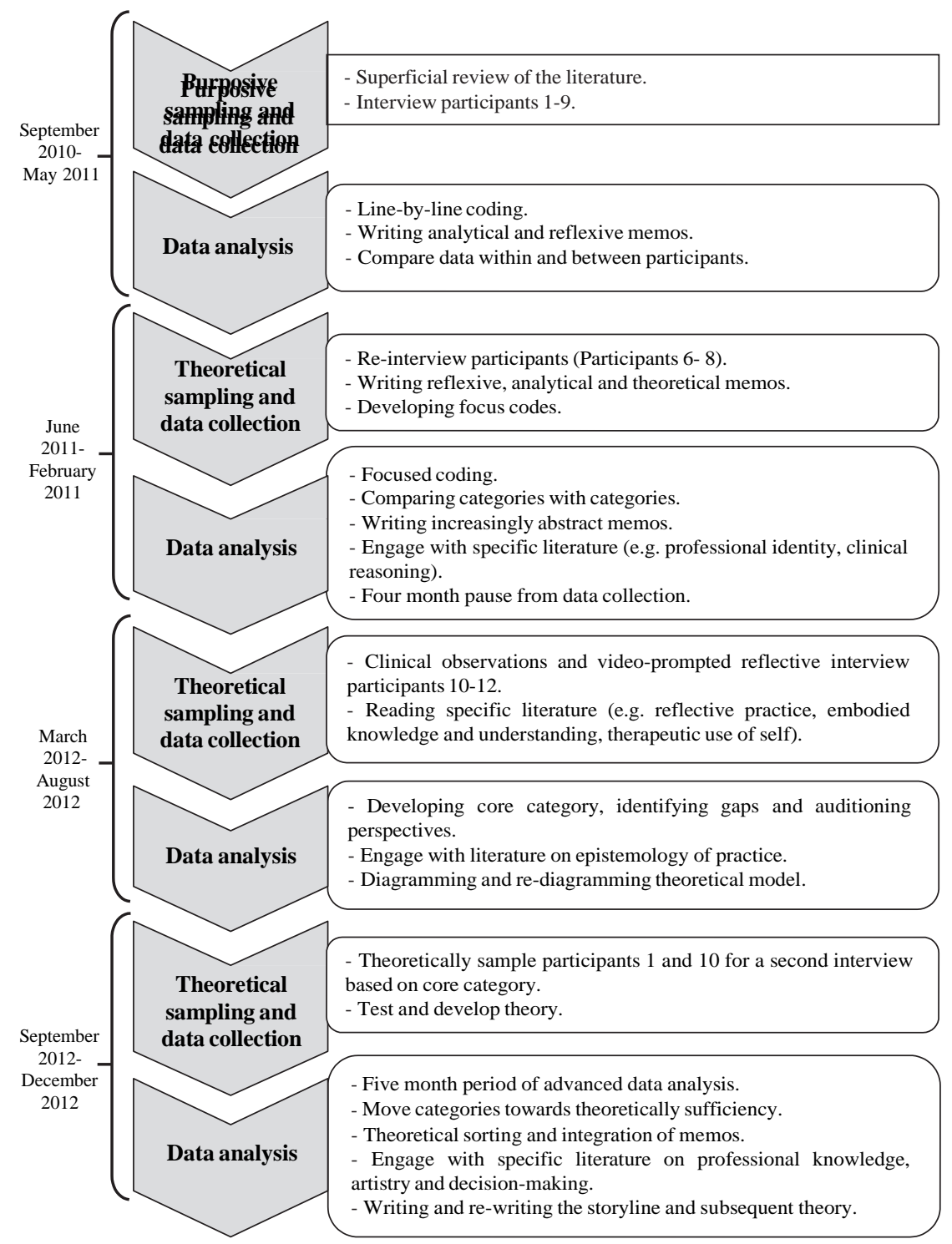

Fig. 1 Summary and timeline of the data collection and analytical processes of a grounded theory study.

data and leads for more data on their question. ${ }^{44}$ In this type of sampling, which often occurs at the initial onset of a grounded theory study, the researcher tries to obtain data from "good informants" (i.e. who are articulate, reflective, and willing to share their views and experiences with the researcher). ${ }^{88, \text { p. }} 127$

Once the researcher gains sufficient theoretical purchase on the data analysis with theoretical insights and ideas, they move to theoretical sampling. The researcher needs to collect data relevant to their developing theoretical ideas, to enable further development of the theory. ${ }^{39}$ Importantly, theoretical sampling also includes reviewing existing key literature which will facilitate theory development, as well as collecting data from specific study participants. Data analysis from the initial purposive sample may result in codes and categories being developed; theoretical sampling enables these to be further defined and refined, and to clarify their relationships to one another. Thus, sampling on theoretical grounds involves actively deciding to collect specific data to help develop categories and their properties. ${ }^{46}$

\section{Example of purposive sampling}

As there was very limited existing research into the clinical decision-making processes used in osteopathy, it was felt that the initial purposive sampling needed to reflect the important focus of the study in producing a starting point theory of clinical 
decision-making. Future research could explore and expand the theory by examining specific aspects, such as expert-novice differences. Recognising the importance of communication in the practice and teaching of clinical reasoning, ${ }^{89}$ purposively sampling osteopaths who could effectively communicate and verbalise their clinical decision-making processes was thought to be vital to obtaining rich data, allowing detailed or 'thick' descriptions, which was critical in establishing credibility and transferability of the research findings. ${ }^{90}$ With this in mind, purposive sampling was used to select osteopaths, with a minimum of five years in clinical practice, and with a minimum of two years' experience in osteopathic clinical education from the osteopathic education institutions throughout the UK.

\section{Example of theoretical sampling}

When using theoretical sampling OT not only had to decide what data to collect and who from, but also consider how data that would help develop the theory was going to be generated. Data analysis from the first nine interviews (from purposively sampled participants) began to suggest that there were three broad therapeutic approaches that characterised participants and their clinical practice. These three approaches influenced how participants interacted with patients and also the level of patient involvement in the clinical decisionmaking. Theoretical sampling was used in three major ways. Firstly, theoretical sampling was used to re-interview three participants who were characterised as one of the three therapeutic approaches. During the interviews with theoretically sampled participants, OT was fully armed with an awareness of the gaps in the developing theory, and through immersion in the data was theoretically sensitive of how to fill them through asking questions around specific areas. Secondly, theoretical sampling also involved moving from individual interviews to clinical observations and videoprompted reflective interviews with three new participants. The clinical observations and videoprompted interviews enabled OT to make theoretical connections between what previous participants had said during individual interviews with what was seen during the observation session, providing new perspectives and further analytical insights. In addition, using the video-recording as a reflective tool during interviews not only reminded participants about the previous clinical session, but it also helped them to reflect more deeply about their clinical practice and decision-making and ensured that their answers to questions were closely tied to their actions and clinical decisions, which took place during the clinical appointment. ${ }^{91}$ For example, participants talked through their specific thinking and reasoning immediately after viewing aspects of their clinical assessment and examination of the patient on the video-recording, and provided specific detail about why they performed a particular clinical procedure in a particular way.

Finally, towards the latter stages of the study OT theoretically sampled two participants for a second interview to explore and test out a proposed 'core category' as well as further develop the theory. ${ }^{92}$ These two interviews provided sufficient data to make sense of the relationship between three key categories: osteopaths' overall conception of practice, their approach to clinical decision-making and their therapeutic approach.

\section{Data collection and analysis in grounded theory research}

In grounded theory, data collection and analysis occur concurrently, which contrasts with other qualitative research methodologies where analysis occurs once all the data is collected. Data collection and analysis is an iterative and cyclical process (Fig. 1), and involves comparing data with data, data with category, category with category, termed the constant comparative method of analysis, ${ }^{44}$ with the researcher looking for patterns in the data including differences and commonalities. ${ }^{39}$ The process of data analysis involves identifying words or lines in the data and labelling them with a code which captures the meaning (based on the researcher's interpretation) of that segment of data. Groups of related codes form more general, abstract categories. As alluded to earlier, there are many different coding strategies, and the process can become complicated such as Strauss and Corbin's ${ }^{35,47}$ coding paradigm or Glaser's ${ }^{44}$ coding families.

A key to a grounded theory being 'grounded' in the data is the type of reasoning approaches that take place during data analysis, termed inductive, deductive and abductive reasoning (illustrated in Fig. 2). Inductive reasoning occurs when the researcher builds patterns, themes and categories from the data, to increasing levels of abstraction to eventually form a concept or theory, based on their interpretation of the data (as indicated by the arrows moving upward from specific data to a general theory in Fig. 2).${ }^{93}$ An everyday example of inductive reasoning is when a practitioner recognises patterns in a patient's symptoms and can quickly build a theory of what might be wrong (i.e. a diagnosis), ${ }^{94}$ such is the case when a patient describes the particular characteristic of their pain and associated 

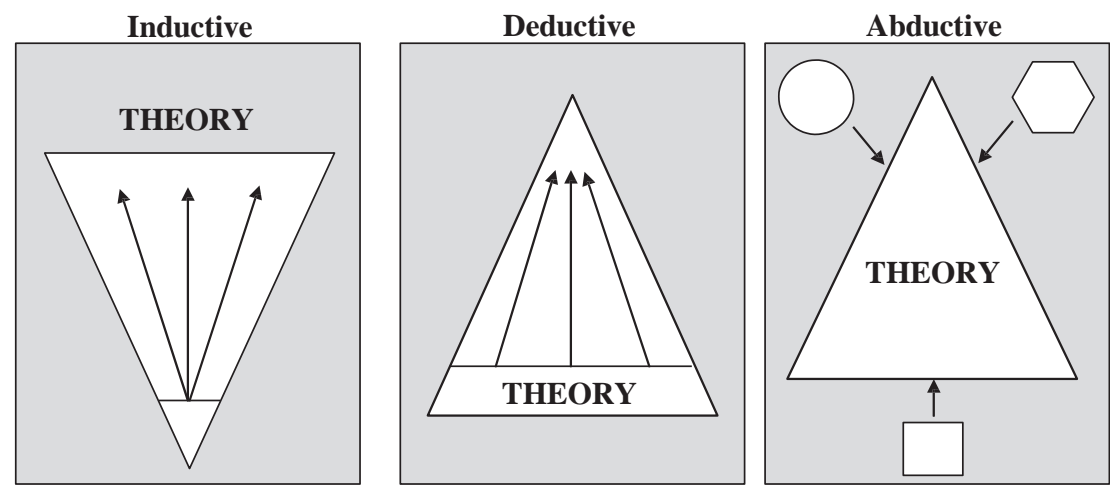

Fig. 2 The inductive, deductive and abductive reasoning approaches used in grounded theory analysis (modified from Nicholls ${ }^{96}$ ).

symptoms which taken together form a pattern suggestive of a radiculopathy. In contrast, during deductive reasoning the researcher starts with a theory or hypothesis and looks to test or verify the hypothesis with further research or analysis (as indicated by the arrows moving upward from a general theory to a specific focal point in Fig. 2). An example of deductive reasoning is when osteopaths have a range of competing hypotheses (differential diagnoses) about what might be the cause of a patient's symptoms. Through further data collection the hypotheses are tested and either accepted or rejected, ${ }^{95}$ such as by using a range of examination procedures to test hypotheses for specific causes of a patient's thoracic pain. Finally, abductive reasoning involves examining the data and then forming multiple hypotheses or ideas that might explain what is 'observed' in the data (as indicated by the multiple arrows moving inward to arrive at a general theory in Fig. 2). These hypotheses are then proved or disproved by re-examining the data and arriving at the most credible interpretation. ${ }^{32}$ An example of abductive reasoning is when a practitioner considers that given a patients' collection of signs and symptoms, then diagnosis ' $X$ ' is the most plausible explanation of the patient's presentation.

When using the constant comparative method in grounded theory research, the recurrent interplay between inductive, deductive and abductive reasoning occurs when the researcher inductively builds a category from the data then looks to deductively test or verify the category during further data collection and analysis. ${ }^{35}$ Abductive reasoning helps researchers make new conceptual and ('serendipitous') theoretical leaps and bring the categories together to a higher level of abstraction. ${ }^{32}$

In grounded theory research, how much data is collected, and for how long, is not predetermined. Data collection and analysis continues until the research reaches what is known as theoretical saturation or theoretical sufficiency. Theoretical saturation was described by the originators of grounded theory, and can be defined as the point at which no new insights are obtained, no new categories are identified, and all major categories are defined and established - that is they are saturated. ${ }^{35}$ However achieving data saturation is not an exact process, and many authors comment on the difficulties in knowing when, or if, saturation has been reached, ${ }^{97}$ and some question whether it can actually ever be attained. ${ }^{32,39,98}$ Therefore, many researchers conducting a grounded theory study in the interpretive paradigm prefer the more flexible notion of theoretical sufficiency, ${ }^{98}$ to suggest when enough data and analysis has been conducted, so that all theoretical claims made by the researcher can be supported by categories and data.

\section{Memo-writing}

Memo-writing is fundamental to developing a grounded theory, regardless of the version of grounded theory that is used. A memo records the researcher's abstract thinking about- and interpretation of the data (Table 7), and they are written throughout the life of the research study. Memos are important in the early stages of data analysis to enable the researcher to make comparisons between data and thus gain an analytical grasp of the data. During the early stages of the study, the researcher notes down questions about the data and any interesting observations, and in this case memos may act as simple analytical tools. Later on, memos can become theoretical tools, where categories and concepts can be integrated and their relationships explored. Often these advanced theoretical memos form the basis of research papers to be published. Throughout the study, memos may also be reflexive tools, whereby the researcher can put into writing any personal feelings and 
Table 7 Memo-writing. 32,39

Memos may include:

Feelings and assumptions about the research to facilitate researcher reflexivity and offset bias.

Define codes and their relationships to other codes and categories.

Identify gaps in categories and noting how they may be 'filled' (e.g. through further data collection, analysis and theoretical sampling).

Interrogate codes by asking questions of the data ('when does this happen, why, what is the outcome of this process?).

Decision-making of the direction of data analysis and sampling.

Table 8 Examples of line-by-line coding of interview data.

\begin{tabular}{ll}
\hline Quote & Line-by-line code \\
\hline I'm being told what to do by what the tissue tells me. So & $\begin{array}{l}\text { Trusting hands } \\
\text { Body directing } \\
\text { I'm not deciding what to do, I'm trying not to do that. }\end{array}$ \\
$\begin{array}{l}\text { I'm trying to assess and let the body tell me what it } \\
\text { wants me to do to it, or what it will permit me to }\end{array}$ & \\
$\begin{array}{l}\text { do. (P2) } \\
\text { asking patients what type of treatment they prefer }\end{array}$ & $\begin{array}{l}\text { Trusting patient } \\
\text { treats them as an adult and gives them the autonomy }\end{array}$ \\
$\begin{array}{l}\text { to say “I don't agree with this and I don't want to do } \\
\text { this; it doesn't fit in with my values, attitudes and }\end{array}$ & Mutual control \\
beliefs and I want to change it" so they feel an equal \\
partnership. (P6)
\end{tabular}

assumptions which develop during analysis, these are then explicated and can be checked out with the data. ${ }^{99}$ In addition, memo-writing throughout the research study contribute to an audit trail ${ }^{90}$ to demonstrate how the study was conducted and explicate how the theory was developed.

\section{Example of data analysis}

During the early stages of data analysis, coding took the form of initial coding, (also termed lineby-line coding), ${ }^{39}$ which involved examining each line of data (in the form of a transcribed interview), which aimed to define actions or events of a given situation. OT endeavoured to remain open and stay close to the data throughout all stages of coding. This was particularly important during the early stages of data analysis so he could look closely and see the nuances of what participants were saying in order to generate analytical leads which could be pursued later on. ${ }^{39}$ At this stage of analysis, action codes, employing gerunds ${ }^{f}$ were also used to give an insight of what participants

\footnotetext{
${ }^{f}$ A gerund is a verb used as noun ending in '-ing'. Using gerunds as codes helps to emphasise the actions and processes within the data. For example, action codes using gerunds employed in this research included; focusing interaction, working with the body and directing patients.
}

were discussing or what processes they were describing during the interview. ${ }^{34}$ During this point in data analysis, an accessory coding strategy was employed by way of the use of in vivo codes. ${ }^{39}$ In vivo codes use terms abstracted from the language of the study participants to label segments of data. ${ }^{39}$ These codes referred directly to the words of participants, and aimed to serve as a symbolic indicator of participants' perspectives, language and meanings. ${ }^{39}$ During all coding procedures, data was compared with data, codes compared with codes, looking for similarities and differences, and actively making analytical distinctions and connections (i.e. constant comparative analysis).

The line-by-line codes developed from initial coding further directed and began to focus data analysis. Coding then moved to a form of intermediate coding, termed focused coding, which was used to assess which codes appeared to be the most significant. ${ }^{39}$ Focused coding enabled larger segments of data to be analysed, allowing OT to begin to make sense of coded data whilst elevating the level of conceptual analysis so that more abstract categories could be developed. As data analysis proceeded, OT attempted to use different coding strategies to gain a different perspective on the developing theory. For example, Strauss and Corbin's axial coding was employed in order to clarify relationships between categories and sub- 
Table 9 Examples of focused coding of interview data.

\begin{tabular}{ll}
\hline Quote & Focused code \\
\hline .there is a lot of talk between you and the person and a lot of & Interacting with the person \\
communication. You are talking to them the whole time, 'how & \\
does the treatment feel'?. [and] you are trying to get a gauge on & \\
how it really feels to them. (P3) & \\
there are times when I think I am being intuitive about what the & Interacting with the body \\
tissues feel like and I'm not actually thinking about what's under & \\
my fingers. It's almost like they're going by themselves. (P8) & Interacting with the patient \\
I go quite heavily into the history of their complaint, their & \\
occupation and what they do on a day-to-day basis and then how \\
that feeds into their aggravating and relieving factors. So [I] try to \\
get quite a clear picture of all the things that bothers them. (P9)
\end{tabular}

Table 10 Four major categories their relationships to each other.

\begin{tabular}{llll}
\hline Characteristic & Therapeutic approach & & \\
\cline { 2 - 4 } & Treater & Communicator & Educator \\
\hline $\begin{array}{l}\text { Approach to clinical } \\
\text { decision-making }\end{array}$ & Practitioner-led & Shared & Patient-led \\
$\begin{array}{l}\text { Patient involvement } \\
\text { Therapeutic goal }\end{array}$ & $\begin{array}{l}\text { Low } \\
\text { Practitioner takes control } \\
\text { and responsibility }\end{array}$ & $\begin{array}{l}\text { Equal } \\
\text { Practitioner shares control } \\
\text { and guides patient }\end{array}$ & $\begin{array}{l}\text { High } \\
\text { Practitioner facilitates } \\
\text { learning and control with } \\
\text { patient }\end{array}$ \\
\hline
\end{tabular}

categories. ${ }^{46}$ Axial coding was a strong feature of Strauss and Corbin's earlier writings ${ }^{47}$ and is used to reassemble 'fractured' data following line-byline coding so that relationships between codes and categories can be developed. ${ }^{47}$ Initially, this was a useful framework and it added some detail to categories, but later on it was found to be rigid and limited OT's thinking. An example of line-byline and focused coding used during the analysis of this study is shown below in Tables 8 and 9 respectively.

Through an iterative process of reading/rereading the transcripts, coding, memo-writing, the line-by-line codes could be grouped into the broader categories of body-focused interaction, person-focused interaction and patientfocused interaction, which suggested that different participants seemed to generate and

\begin{tabular}{|c|}
\hline $\begin{array}{l}\text { Are the therapeutic approaches favoure } \\
\text { range of therapeutic 'options' which al } \\
\text { individual patient and their situation? }\end{array}$ \\
\hline $\begin{array}{l}\text { What are the influencing factors which might result in a participant favouring a } \\
\text { particular therapeutic approach? How has this developed and what are the } \\
\text { conditions? }\end{array}$ \\
\hline $\begin{array}{l}\text { Can participants change their approach? If so what are the triggers and what are the } \\
\text { consequences? Can others not change their approach? Why? }\end{array}$ \\
\hline $\begin{array}{l}\text { What are participants 'doing' and what is 'going on' when participants adopt a } \\
\text { particular approach? What are the consequences of this process? }\end{array}$ \\
\hline $\begin{array}{l}\text { Some participants appear to be more rigid in their practice, whilst others appear } \\
\text { more adaptable. Why is this the case? }\end{array}$ \\
\hline
\end{tabular}

Fig. 3 Example of an analytical memo. 
Table 11 Critical appraisal tool for qualitative research (modified from CASP ${ }^{104}$ ).

Appraisal questions
the aims of the research?
Is a qualitative methodology
appropriate?
Was the research design
appropriate to address the
aims of the research?
Was the recruitment strategy
appropriate to the aims of
the research?

Were the data collected in a way that addressed the research issue?

Has the relationship between researcher and participants been adequately considered?

Have ethical issues been taken into consideration?

Was the data analysis sufficiently rigorous?

How valuable is the research?
Examples

What were the goals of the research and were they clear and explicit? Why is it important or relevant (e.g. to clinical practice, education, patient care)?

Does the research seek to interpret or illuminate the actions and/or subjective experiences of research participants?

Has the researcher justified the research design (e.g. have they discussed how they decided which method to use)?

Have the researchers explained how participants were selected/sampled (e.g. specific details on purposeful and theoretical sampling procedures)?

Consider if they explained why the participants they selected were the most appropriate to provide access to the type of knowledge sought by the study. Is clear how data were collected (e.g. focus group, semi-structured interview, observation)?

Have the researchers justified the data collection methods chosen?

Have the researchers made these methods explicit (e.g. for interview method, is there an indication of how interviews were conducted, or did they use a topic guide)?

Were the methods modified during the study? If so, has the researcher explained how and why?

Consider if the form of data is clear (e.g. audio recordings, video material, field notes etc.).

Have the researchers discussed saturation/sufficiency of data?

Are any of the researchers 'insiders' (e.g. practitioners researching aspects of their own practice/profession)?

Do any of the researchers have existing/prior knowledge, awareness or relationships with participants?

Consider:

If there are sufficient details of how the research was explained to participants for the reader to assess whether ethical standards were maintained.

If the researcher has discussed issues raised by the study (e.g. issues around informed consent or confidentiality or how they have handled the effects of the study on the participants during and after the study).

Has approval been obtained from an ethics committee.

Is there an in-depth description of the data analysis process? Are examples of data analysis provided?

How were the categories derived from the data? How were they developed and relationships between them formed?

Consider whether the researcher explains how the data presented were selected from the original sample to demonstrate the analysis process.

Is sufficient data are presented to support the findings and theoretical claims?

Are multiple perspectives, voices and contradictory views presented?

Do the researchers critically examine their own role, potential bias and influence during analysis and selection of data for presentation? What strategies were taken to offset this bias (e.g. reflective diary, member-checking, welldeveloped researcher-participant relationship)?

Do the researchers discuss the contribution the study makes to existing knowledge or understanding e.g. do they consider the findings in relation to current practice, education or policy, or relevant research-based literature? Consider if they identify new areas where research is necessary

Have the researchers discussed whether or how the findings can be transferred to other populations or considered other ways the research may be used? 
Table 12 Strategies used to enhance and evaluate the trustworthiness of the grounded theory case example.

\begin{tabular}{|c|c|c|}
\hline & Description $^{90}$ & Strategies \\
\hline Credibility & $\begin{array}{l}\text { Confidence that the research has } \\
\text { obtained an accurate } \\
\text { interpretation of the meaning of } \\
\text { the data which reflects the } \\
\text { experience of participants. }\end{array}$ & $\begin{array}{l}\text { - Prolonged immersion in the data ( } 3 \text { years) } \\
\text { - Insider position as an osteopath provided } \\
\text { opportunities to informally verify, test and } \\
\text { check the theory as it was constructed } \\
\text { during the analysis. } \\
\text { - Member checking e Participants were } \\
\text { asked to read through the interview tran- } \\
\text { script to confirm that it represented an } \\
\text { accurate account of what was said, and } \\
\text { were encouraged to add any further com- } \\
\text { ments that they felt necessary. } \\
\text { - Peer debriefing in the form of feedback } \\
\text { from the peer review process following the } \\
\text { submission of sections of study to research } \\
\text { journals and conferences. } \\
\text { - A well-developed researcher-participant } \\
\text { relationship so that participants had trust } \\
\text { in disclosing personal details of their } \\
\text { clinical practice. } \\
\text { - A reflexive diary was kept to disclose as- } \\
\text { sumptions, biases and beliefs, and how } \\
\text { they may shape on the research findings }\end{array}$ \\
\hline Transferability & $\begin{array}{l}\text { Transferability is the extent to } \\
\text { which the ideas generated may be } \\
\text { applied to other populations or } \\
\text { situations, and may be considered } \\
\text { the theoretical generalisability of } \\
\text { the findings. }\end{array}$ & $\begin{array}{l}\text { - During interviews, the goal was to obtain } \\
\text { "thick descriptions", i.e. those which are } \\
\text { "deep, dense, detailed accounts"105, p. } 83 \\
\text { - Ideas and theories were discussed with } \\
\text { osteopathic colleagues and the developing } \\
\text { theory was tested out during conference } \\
\text { presentations. }\end{array}$ \\
\hline $\begin{array}{l}\text { Dependability } \\
\text { and } \\
\text { confirmability }\end{array}$ & $\begin{array}{l}\text { The degree to which the researcher } \\
\text { can demonstrate that the findings } \\
\text { relate to the data. Whether the } \\
\text { findings of the study offer a } \\
\text { dependable and realistic } \\
\text { interpretation of the view held by } \\
\text { the participants. }\end{array}$ & $\begin{array}{l}\text { An audit trail in the form of memos, } \\
\text { reflexive diary and interview transcripts so } \\
\text { that the reader can follow the research } \\
\text { process. }\end{array}$ \\
\hline
\end{tabular}

interpret cues (information) through different forms of interaction (Table 9). Focused coding then used these more abstract labels to code larger segments of data.

Identifying and explaining relationships between categories and concepts are part of what forms a grounded theory, as how these categories link or integrate will explain a process or action. For example, the broad category of level of patient involvement was related to the categories of approach to clinical decision-making, the therapeutic approach that practitioners took with their patients and their intended therapeutic goal. If, for example, a practitioner interacted with the body, then they would be adopting a Treater therapeutic approach, with the intended outcome to take control of the patient's problem (e.g. pain or dysfunction). During this process, the decision- making appeared to be practitioner-led, with a low level of patient involvement. This was in contrast to other participants who were characterised as adopting an Educator therapeutic approach, and sought to facilitate learning and control with the patient, resulting in patient-led decision-making with a high level of patient involvement. Finally, other participants were characterised as Communicators, and aimed to guide patients and encouraged an equal level of patient involvement so that clinical decisionmaking was shared. Table 10 illustrates four major categories of therapeutic approach, approach to clinical decision-making, level of patient involvement and therapeutic goal constructed in this grounded theory case example.

These categories and their relationships (Table 10) suggested that practitioners took different 
approaches to their decision-making depending on their therapeutic approach. Fig. 3 shows an example of an analytical memo written during the later advanced of data collection and analysis, and explored the relationship between these categories.

\section{Selecting a core category}

In the later stages of a grounded theory study, the researcher often selects one of the major categories as a 'core category'. A core category is considered to be both abstract and explanatory so that it encapsulates and explains the entire grounded theory. ${ }^{32}$ Strauss and Corbin state that a core category should represent the central focus of the phenomenon under study. ${ }^{46}$ Identifying a core category helps to organise the categories into a process or hierarchy, and thereby explain the variations in the data. Furthermore, it forces the researcher to develop a conceptual theory with real explanatory power, rather than merely a superficial description. ${ }^{54,92}$ However, deciding on a core category can be a challenging process for many researchers, especially when there appear to be many important categories, all of which appear vital to explain the study's findings. In this study, the core category needed to explain the variation in participants' therapeutic approaches and clinical decision-making, and how these developed. Through a process of moving back and forth between engaging with the data and engaging with the literature around epistemology of practice, technical rationality and professional artistry $^{21,28}$ the category of conception of practice was selected as the core category. This core category pulled the theory together, and provided order to all categories thereby helping to get behind and explain the differences between the variations in therapeutic and clinical decisionmaking approaches (see Thomson et al., ${ }^{11}$ for a full discussion of the core category).

\section{Ensuring the quality of grounded theory research}

The application of the term 'rigour' in qualitative research is much debated, ${ }^{100} 103$ and researchers have yet to reach consensus on common criteria for judging the quality of qualitative research, mainly due to the different paradigms and philosophical stances which qualitative researchers may take. Table 11 summarises one commonly used tool to evaluate qualitative research, and may be used to critically appraise a grounded theory study.
While the originators of grounded theory developed their own criteria to assess the rigour and merit of a grounded theory study, ${ }^{35,44}$ the positivistic assumptions of the traditional grounded theory mean that these criteria do not often lend themselves to grounded theory conducted in the interpretive research paradigm. More suitable to interpretive research, is the concept of 'trustworthiness', which moves the responsibility for judging the quality of the research from the producer to the reader. ${ }^{101}$ Trustworthiness provides and additional approach to assess the quality of qualitative research, and it encompasses the four criteria of; credibility, transferability, dependability and confirmability which are used to replace the criteria of rigour in the positivist paradigm of internal and external validity, reliability and objectivity ${ }^{90}$ Each criterion of trustworthiness in relation to this grounded theory case example are shown in Table 12. However, demonstrating trustworthiness of grounded theory studies (and qualitative research in general) in journal articles is challenging as there is limited space to provide details of all the processes and procedures outlined in Table 12 . Where a study is conducted as part of an academic award such as a doctorate, obtaining the thesis would enable a reader to better judge the trustworthiness of a study (for example Thomson ${ }^{9}$ ).

\section{Conclusion}

Grounded theory research within osteopathy may be of value to further develop and understand a variety of processes and interactions that occur in clinical practice, including the clinical decisionmaking processes and therapeutic approaches of practitioners, as explored in this paper. This Masterclass has sought to describe and explain, through the extant literature and a case example, the central tenets of grounded theory. This may be of help to osteopaths undertaking such research and to those reading and critically evaluating published grounded theory studies.

\section{Acknowledgements}

Thanks to the British College of Osteopathic Medicine, the British Naturopathic and Osteopathic Association and the Osteopathic Educational Foundation for helping to fund this doctoral research. Thanks to Professor Ann Moore who together with Dr Nikki Petty supervised OT's PhD research study. 


\section{References}

1. Petty NJ, Thomson OP, Stew G. Ready for a paradigm shift? Part 1: introducing the philosophy of qualitative research. Man Ther 2012;17:267e74.

2. Petty NJ, Thomson OP, Stew G. Ready for a paradigm shift? Part 2: introducing qualitative research methodologies and methods. Man Ther 2012;17:378e84.

3. Grant A. The use of qualitative research methodologies within musculoskeletal physiotherapy practice. Man Ther 2005;10:1e3.

4. Shepard KF, Jensen GM, Schmoll BJ, Hack LM, Gwyer J. Alternative approaches to research in physical therapy: positivism and phenomenology. Phys Ther 1993;73:88e97.

5. Jensen GM. Qualitative methods in physical therapy research: a form of disciplined inquiry. Phys Ther 1989;69:492e500.

6. Adams J, Broom A, Jennaway M. Qualitative methods in chiropractic research: one framework for future inquiry. $J$ Manipulative Physiol Ther 2008;31:455e60.

7. Thomson OP, Petty NJ, Ramage CM, Moore AP. Qualitative research: exploring the multiple perspectives of osteopathy. Int J Osteopathic Med 2011;14:116e24.

8. Jenner B, Titscher S. Methods of text and discourse analysis: in search of meaning. SAGE Publications; 2000.

9. Thomson OP. Clinical decision making and therapeutic approaches of experienced osteopaths. Unpublished PhD thesis. University of Brighton; 2013.

10. Thomson OP, Petty NJ, Moore AP. Clinical decision-making and therapeutic approaches in osteopathy e a qualitative grounded theory study. Man Ther 2013. http://dx.doi.org/ 10.1016/j.math.2013.07.008.

11. Thomson OP, Petty NJ, Moore AP. A grounded theory study of the conceptions of practice in osteopathy: a continuum from technical rationality to professional artistry. Man Ther 2013. http://dx.doi.org/10.1016/j. math.2013.06.005.

12. Grundy M, Vogel $S$. Attitudes towards prescribing rights: a qualitative focus group study with UK osteopaths. Int $J$ Osteopathic Med 2005;8:12e21.

13. Strauss AL. Qualitative analysis for social scientists. Cambridge University Press; 1987.

14. Zamani J, Vogel S, Moore A, Lucas K. Analysis of exercise content in undergraduate osteopathic education $e$ a content analysis of UK curricula. Int J Osteopathic Med 2007; 10:97e103.

15. Carnes $D$, Underwood $M$. The importance of monitoring patient's ability to achieve functional tasks in those with musculoskeletal pain. Int J Osteopathic Med 2008;11:26e32.

16. Hartup JK, Murphy RA, Plowman LM, Myers R. Progression through osteopathic training in Australia: the student experience. Int J Osteopathic Med 2010;13:160e5.

17. Colaizzi PF. Psychological research as the phenomenologist views it. In: Valle RS, King M, editors. Existentialphenomenological alternatives for psychology. Oxford University Press; 1978. p. 48e71.

18. Humpage $C$. Opinions on research and evidence based medicine within the UK osteopathic profession: a thematic analysis of public documents 2003e2009. Int J Osteopathic Med 2011;14:48e56.

19. Thomson OP, Petty NJ, Moore AP. Reconsidering the patient-centeredness of osteopathy. Int J Osteopathic Med 2013;16:25e32.

20. Bensing J. Bridging the gap: the separate worlds of evidence-based medicine and patient-centered medicine. Patient Educ Couns 2000;39:17e25.
Schön DA. The reflective practitioner: how professionals think in action. Nueva York, EUA: Basic Books; 1983.

22. Todres L. Embodied enquiry: phenomenological touchstones for research, psychotherapy and spirituality. Basingstoke, UK: Palgrave Macmillan; 2011.

23. Polanyi M. The tacit dimension. London: Routledge \& Kegan Paul; 1967.

24. Higgs J, Titchen A. Practice knowledge and expertise in the health professions. Oxford: Butterworth-Heinemann; 2001.

25. Higgs J, Titchen A. Rethinking the practice-knowledge interface in an uncertain world: a model for practice development. Br J Occup Ther 2001;64:526e33.

26. Eraut M. Developing professional knowledge and competence. London: Falmer; 1994.

27. Fish D. Appreciating practice in the caring professions: refocusing professional development and practitioner research. Oxford: Butterworth-Heinemann; 1998.

28. Fish D, Coles C. Developing professional judgement in health care: learning through the critical appreciation of practice. Oxford; Boston: Butterworth-Heinemann; 1998.

29. Starks H, Brown Trinidad S. Choose your method: a comparison of phenomenology, discourse analysis, and grounded theory. Qual Health Res 2007;17:1372.

30. Guba E, Lincoln Y. Competing paradigms in qualitative research. In: Denzin NK, Lincoln YS, editors. Handbook of qualitative research. Thousand Oaks, Calif.; London: Sage Publications; 1994. p. 105e17.

31. Bryman A. Social research methods. 3rd ed. Oxford: Oxford University Press; 2008.

32. Birks M, Mills J. Grounded theory: a practical guide. Los Angeles, Calif.; London: Sage; 2011.

33. Glaser BG, Strauss AL. Discovery of grounded theory: strategies for qualitative research [S.l.]. Weidenfeld and Nicolson; 1967.

34. Charmaz K. Grounded theory: objectivist and contrstructivist methods. In: Denzin NK, Lincoln YS, editors. Handbook of qualitative research. 2nd ed. Thousand Oaks, Calif.; London: Sage Publications; 2000. p. 509e35.

35. Strauss A, Corbin J. Basics of qualitative research: techniques and procedures for developing grounded theory. 2nd ed. Thousand Oaks: Sage Publications; 1998.

36. Bryant A. Re-grounding grounded theory. J Inf Technol Theor Appl 2002;4:25e42.

37. Babchuk WA. Grounded theory 101: strategies for research and practice. In: Midwest research-to-practice conference. Chicago, IL: Northeastern Illinois University; 2009.

38. Bryant A, Charmaz K. Grounded theory research: methods and practices. In: Bryant A, Charmaz K, editors. The SAGE handbook of grounded theory. London: SAGE; 2007. p. $1 \mathrm{e} 28$.

39. Charmaz K. Constructing grounded theory. London; Thousand Oaks, Calif.: Sage Publications; 2006.

40. Blumer $\mathrm{H}$. Symbolic interactionism: perspective and method. Univ of California Press; 1986.

41. Corbin JM, Strauss AL. Basics of qualitative research: techniques and procedures for developing grounded theory. Sage Publications, Inc.; 2008.

42. Mills J, Chapman Y, Bonner A, Francis K. Grounded theory: a methodological spiral from positivism to postmodernism. J Adv Nurs 2007;58:72e9.

43. Morse JM. Developing grounded theory: the second generation. Walnut Creek, Calif.: Left Coast: Oxford: Berg, Distributor; 2009.

44. Glaser BG. Theoretical sensitivity: advances in the methodology of grounded theory. Mill Valley, Calif.: Sociology Press; 1978.

21. 
45. Glaser BG. Basics of grounded theory analysis: emergence vs forcing. Mill Valley, Calif.: Sociology Press; 1992.

46. Corbin J, Strauss A. Grounded theory research: procedures, canons, and evaluative criteria. Qual Sociol 1990; 13:3e21.

47. Strauss A, Corbin J. Grounded theory methodology: an overview. In: Denzin NK, Lincoln YS, editors. Handbook of qualitative research. Thousand Oaks, Calif.; London: Sage Publications; 1994. p. $275 e 86$.

48. Strauss AL, Corbin JM. Basics of qualitative research: grounded theory procedures and techniques. Sage Publications; 1990.

49. Mills J, Bonner A, Francis K. Adopting a constructivist approach to grounded theory: implications for research design. Int J Nurs Pract 2006;12:8e13.

50. Mills J, Bonner A, Francis K. The development of constructivist grounded theory. Int J Qual Methods 2006;5:1e10.

51. Urquhart C, Lehmann H, Myers MD. Putting the 'theory' back into grounded theory: guidelines for grounded theory studies in information systems. Inf Syst J 2010;20:357e81.

52. Annells M. Grounded theory method: philosophical perspectives, paradigm of inquiry, and postmodernism. Qual Health Res 1996;6:379e93.

53. Glaser BG. Conceptualization: on theory and theorizing using grounded theory. Int J Qual Methods 2008;1:23e38.

54. Glaser BG. Constructivist grounded theory? Forum Qual Sozialforschung/Forum Qual Social Res 2002;3.

55. Clarke A. Situational analysis: grounded theory after the postmodern turn. Thousand Oaks, Calif.; London: Sage Publications; 2005.

56. Jette DU, Grover L, Keck CP. A qualitative study of clinical decision making in recommending discharge placement from the acute care setting. Phys Ther 2003;83:224e36.

57. Edwards I, Jones M, Carr J, Braunack-Mayer A, Jensen GM. Clinical reasoning strategies in physical therapy. Phys Ther 2004;84:312e30.

58. Jensen GM, Gwyer J, Shepard KF. Expert practice in physical therapy. Phys Ther 2000;80:28e43 [discussion 44e52].

59. Resnik L, Jensen GM. Using clinical outcomes to explore the theory of expert practice in physical therapy. Phys Ther 2003;83:1090e106.

60. Beech N, Arber A, Faithfull S. Restoring a sense of wellness following colorectal cancer: a grounded theory. J Adv Nurs 2012;68:1134e44.

61. Benoliel JQ. Grounded theory and nursing knowledge. Qual Health Res 1996;6:406e28.

62. MCCann T, Clark E. Grounded theory in nursing research: part 1 e methodology. Nurse Res 2003;11:7.

63. Scholes J, Endacott R, Biro M, Bulle B, Cooper S, Miles M, et al. Clinical decision-making: midwifery students' recognition of, and response to, post partum haemorrhage in the simulation environment. BMC Pregnancy Childbirth 2012;12:19.

64. Bhandari M, Montori V, Devereaux PJ, Dosanjh S, Sprague S, Guyatt GH. Challenges to the practice of evidence-based medicine during residents' surgical training: a qualitative study using grounded theory. Acad Med 2003;78:1183e90.

65. Kennedy TJ, Regehr G, Baker GR, Lingard L. Preserving professional credibility: grounded theory study of medical trainees' requests for clinical support. BMJ Br Med J 2009; 338.

66. Shepard KF, Hack LM, Gwyer J, Jensen GM. Describing expert practice in physical therapy. Qual Health Res 1999; 9:746e58.

67. Edwards I, Jones M, Higgs J, Trede F, Jensen $G$. What is collaborative reasoning? Adv Physiother 2004;6:70e83.
68. Edwards I, Richardson B. Clinical reasoning and population health: decision making for an emerging paradigm of health care. Physiother Theory Pract 2008;24:183e93.

69. Smith M, Higgs J, Ellis E. Characteristics and processes of physiotherapy clinical decision making: a study of acute care cardiorespiratory physiotherapy. Physiother Res Int 2008; 13:209e22.

70. Smith M, Joy H, Ellis E. Effect of experience on clinical decision making by cardiorespiratory physiotherapists in acute care settings. Physiother Theory Pract 2010;26:89e99.

71. Resnik L, Hart DL. Using clinical outcomes to identify expert physical therapists. Phys Ther 2003;83:990e1002.

72. Petty NJ, Scholes J, Ellis L. The impact of a musculoskeletal masters course: developing clinical expertise. Man Ther 2011;16:590e5.

73. Petty NJ, Scholes J, Ellis L. Master's level study: learning transitions towards clinical expertise in physiotherapy. Physiotherapy 2011;97:218e25.

74. Jamison JR. An interactive model of chiropractic practice: reconstructing clinical reality. J Manip Physiol Ther 1997; 20:382.

75. Strauss A, Corbin J. Grounded theory methodology: an overview. In: Denzin NK, Lincoln YS, editors. Handbook of qualitative research, vol. xii. Thousand Oaks, Calif.; London: Sage Publications; 1994. p. 643.

76. Evans D, Foster N, Vogel S, Breen A, Underwood $M$, Pincus T. Low back pain beliefs and reported practice of three healthcare professions in the UK. In: International forum VII for primary care research on low-back pain. Edmonton, Alberta, Canada 2004.

77. Evans D. Changing the practice of osteopaths, chiropractors and musculoskeletal physiotherapists, in relation to the management of low back pain. Unpublished PhD thesis. Keele University; 2007.

78. Chaffey L, Unsworth C, Fossey E. A grounded theory of intuition among occupational therapists in mental health practice. Br J Occup Ther 2010;73:300e8.

79. Petty NJ. Towards clinical expertise: learning transitions of neuromusculoskeletal physiotherapists. Unpublished doctoral thesis. University of Brighton; 2009.

80. Schatzman L. Dimensional analysis: notes on an alternative approach to the grounding of theory in qualitative research. In: Maines DR, editor. Social organization and social process. New York: A. de Gruyter; 1991.

81. Sexton M. Patient-centred care: an exploration of its meaning for musculoskeletal physiotherapists and patients with low back pain. University of Brighton; 2011. Unpublished doctoral thesis.

82. Higgs J, Jones $M$. Clinical decision making and multiple problem spaces. In: Higgs J, Jones M, Loftus S, Christensen N, editors. Clinical reasoning in the health professions. 3rd ed. Oxford: Elsevier Butterworth-Heinemann; 2008. p. 3e18.

83. Annells M. Grounded theory method, part I: within the five moments of qualitative research. Nurs Inq 1997;4:120e9.

84. Bryant A. A constructive/ist response to Glaser. About Barney G. Glaser: constructivist grounded theory? Published in FQS 3(3). Forum Qual Sozialforschung/Forum Qual Soc Res 2003;4.

85. Bryant T. Grounding systems research: re-establishing grounded theory. In: Proceedings of the 35th annual Hawaii international conference on system sciences (HICSS'02), vol. 8. IEEE Computer Society; 2002; 253.3.

86. Urquhart $C$. Regrounding grounded theory or reinforcing old prejudices? A brief reply to Bryant. J Inf Technol Theor Appl 2002;4:43e54.

87. Patton MQ. Qualitative research and evaluation methods. 3rd ed. London: SAGE; 2002. 
88. Morse JM. Strategies for sampling. In: Morse JM, editor. Qualitative nursing research: a contemporary dialogue. Rev. ed. Newbury Park, Calif.; London: Sage Publications; 1991. p. 127e45.

89. Ajjawi R, Higgs J. Learning to communicate clinical reasoning. In: . Higgs J, Jones $M$, Loftus $S$, Christensen $N$, editors. Clinical reasoning in the health professions. 3rd ed., vols. 321e338. Amsterdam: Butterworth Heinemann; 2008.

90. Lincoln YS, Guba EG. Naturalistic inquiry. Beverly Hills, Calif.: Sage Publications; 1985.

91. Haw K, Hadfield M. Video in social science research: functions and forms. Routledge; 2011.

92. Cutcliffe JR. Methodological issues in grounded theory. $J$ Adv Nurs 2000;31:1476e84.

93. Blaikie N. Approaches to social enquiry. Cambridge: Polity Press; 1993.

94. Groen GJ, Patel VL. Medical problem-solving: some questionable assumptions. Med Educ 1985;19:95e100.

95. Jones MA. Clinical reasoning in manual therapy. Phys Ther 1992;72:875e84.

96. Nicholls D. Qualitative research: part one e philosophies. Int J Ther Rehabil 2009;16:526e33.

97. Bowen GA. Naturalistic inquiry and the saturation concept: a research note. Qual Res 2008;8:137e52.
Dey I. Grounding grounded theory: guidelines for qualitative inquiry. San Diego: Academic Press; 1999.

99. Cutcliffe JR. Reconsidering reflexivity: introducing the case for intellectual entrepreneurship. Qual Health Res 2003; 13:136e48.

100. Morse JM, Barrett M, Mayan M, Olson K, Spiers J. Verification strategies for establishing reliability and validity in qualitative research. Int $J$ Qual Methods 2002;1.

101. Rolfe G. Validity, trustworthiness and rigour: quality and the idea of qualitative research. J Adv Nurs 2006;53: $304 e 10$.

102. Sandelowski $M$. The problem of rigor in qualitative research. ANS Adv Nurs Sci 1986;8:27e37.

103. Sandelowski $M$. Rigor or rigor mortis: the problem of rigor in qualitative research revisited. Adv Nurs Sci 1993;16: 1 e8.

104. CASP. Critical appraisal skills programme. Critical appraisal of qualitative research. UK. Available from:, http://www.casp-uk.net/workshops/casp-workshops/ casp-critical-appraisal-workshops/critical-appraisal-ofqualitative-research/; 2013.

105. Denzin N. Interpretive interactionism. Newbury Park: Sage Publications; 1989.

98. 